\title{
Century-scale records of land-based activities recorded in Mesoamerican coral cores
}

\author{
Jessica E. Carilli ${ }^{\text {a, }}$, Nancy G. Prouty ${ }^{\text {b,c }}$, Konrad A. Hughen ${ }^{\text {b }}$, Richard D. Norris ${ }^{\text {a }}$ \\ ${ }^{a}$ Scripps Institution of Oceanography, University of California, San Diego, 9500 Gilman \\ Dr. 0208, La Jolla, CA 92093, USA \\ ${ }^{\mathrm{b}}$ Woods Hole Oceanographic Institution, 360 Woods Hole Rd., Woods Hole, MA 02543 , \\ USA \\ ${ }^{\mathrm{c}}$ Present address: United States Geological Survey, Pacific Sciences Center, 400 Natural \\ Bridges Drive, Santa Cruz, CA 95060, USA \\ * Corresponding Author: Jessica Carilli, jcarilli@ucsd.edu, phone 001-858-822-2783, fax \\ 001-858-822-3310
}

\begin{abstract}
The Mesoamerican Reef, the second-largest barrier reef in the world, is located in the western Caribbean Sea off the coasts of Mexico, Belize, Guatemala, and Honduras. Particularly in the south, the surrounding watersheds are steep and the climate is extremely wet. With development and agricultural expansion, the potential for negative impacts to the reef from land-based runoff becomes high. We constructed annually resolved century-scale records of metal/calcium ratios in coral skeletons collected from four sites experiencing a gradient of land-based runoff. Our proxy data indicate that runoff onto the reef has increased relatively steadily over time at all sites, consistent with land use trends from historical records. Sediment supply to the reef is greater in the south, and these more exposed reefs will probably benefit most immediately from management that targets runoff reduction. However, because runoff at all sites is steadily increasing, even distal sites will benefit from watershed management.
\end{abstract}

Keywords: Montastraea faveolata, heavy metals, sedimentation, runoff

\section{Introduction}

Land use in Mesoamerica is following the trajectory seen in many locations worldwide: as population increases, development increases and agricultural areas expand into native habitat (Fig. 1). Agricultural intensification and development are usually associated with increased erosion and sediment-laden runoff (Matson et al., 1997). Land-use change tends to increase both the amount of freshwater runoff and the sediment content of that runoff (Foley et al., 2005). Indeed, Burke and Sugg (2006) modeled runoff between natural land cover and the altered land cover in the watersheds surrounding the Mesoamerican Reef in 2004, and found a doubling of overall freshwater runoff and a 20fold increase in the amount of sediment eroded, as well as much higher levels of nutrient runoff as well. Here we use the term runoff to encompass both of these possible scenarios (an increase in the total amount of freshwater discharge and an increase in the amount of contaminants in that discharge), which are not mutually exclusive. Burke and Sugg 
(2006) and Thattai et al. (2003) also showed that the majority of sedimentation and nutrient runoff in the region originates in Honduras, while Kok (2004) showed that agricultural expansion of many products in Honduras is concentrated in watersheds draining into the Gulf of Honduras. Therefore, we would expect runoff impacts to the reef to be higher in the south, and to have increased over time.

Runoff from land can have deleterious effects on corals. Sediment particles may smother and abrade the coral animal, and suspended matter reduces light incidence and photosynthesis in the coral's algal symbionts (Dodge and Vaisnys, 1977; Rogers, 1990). Sedimentation can lead to reduced skeletal growth rates (Dodge and Vaisnys, 1977), reduced fecundity (Kojis and Quinn, 1984), and changes in community structure (Rogers, 1990). Heavy metal pollution from runoff is also a concern for corals. For instance, Negri and Heyward (2001) found that copper and tributylin inhibit fertilization and larval metamorphosis in Acropora millepora, and Richmond (1993) and Peters et al. (1997) both reviewed several studies that found negative effects due to metal exposure, including coral bleaching (the loss of symbiotic algae) and death. Coral health in Mesoamerica has recently declined, as shown by growth rates (Carilli et al., in press) and ecological surveys (McClanahan et al., 1999; McField, 1999). Therefore, we were interested in investigating the link between coral reef health and changes in runoff as documented in both historical records and coral proxy records recovered from geochemical time-series.

We used drill cores from massive corals heads to document temporal trends in runoff to the reef system. Scleractinian corals can live for hundreds of years and continuously record changes in the marine environment in their aragonitic skeletons. Annual density banding in corals allows accurate time control on reconstructions (Knutson et al., 1972), and many studies have utilized corals for paleoclimatic and paleoenvironmental reconstruction, measuring stable isotopes (Dunbar et al., 1994; Cobb et al., 2003, Marion et al., 2005) and metals that substitute into the $\mathrm{CaCO}_{3}$ matrix (Smith et al., 1979; Hanna and Muir, 1990; Bastidas and Garcia, 1999; Fallon et al., 2002; David, 2003; McCulloch et al., 2003; Ramos et al., 2004; Fleitmann et al., 2007; Lewis et al., 2007; Prouty et al., 2008). Although the coral calcification mechanism and therefore the exact pathway of metal substitution in the aragonite matrix are still under debate (Cohen and McConnaughey, 2003), empirical studies have shown that corals appear to faithfully record relative metal concentrations in the surrounding seawater (Runnalls and Coleman, 2003; Correge, 2006).

In this paper we extend the temporal records of seven metals that Prouty et al. (2008) found to be well suited as indicators of environmental change in Montastraea faveolata from four sites on the Mesoamerican Reef: Turneffe Atoll, the Sapodilla Cayes, Utila, and Cayos Cochinos (Fig. 2). Here we present annually-resolved, century-scale records of $\mathrm{Ba} / \mathrm{Ca}$ (barium), $\mathrm{Mn} / \mathrm{Ca}$ (manganese), $\mathrm{Cr} / \mathrm{Ca}$ (chromium), $\mathrm{Sb} / \mathrm{Ca}$ (antimony), $\mathrm{Cu} / \mathrm{Ca}$ (copper), $\mathrm{Pb} / \mathrm{Ca}$ (lead) and $\mathrm{Zn} / \mathrm{Ca}$ (zinc) (Table 1). Our sites span a gradient of hypothesized land-based influence, with higher runoff impacts in the south and lower impacts towards the north and farther from land (Burke and Sugg, 2006; Chérubin et al., 2008). Records of trace metal variation were constructed over the past 100-150 years to 
investigate how land-based runoff has changed over this time period. In addition, water samples were collected from offshore transects and all metals were analyzed and compared to maps of chlorophyll-a to investigate spatial patterns related to coastal runoff.

\section{Background}

The selected metals are indicators of a variety of land-based sources ranging from terrigenous sedimentation to mining waste. Coral $\mathrm{Ba} / \mathrm{Ca}$ ratios have been used as tracers of sediment runoff, since Ba desorbs from terrigenous particles when fresh and saltwater mix (Alibert et al., 2003; McCulloch et al., 2003; Fleittman et al., 2007). Mn tracks primary productivity, which would be influenced by nutrient delivery from rivers and therefore also reflect variations in terrestrial runoff (Abram et al., 2003; Alibert et al., 2003). The other metal/Ca ratios can also indicate impacts due to land-based activities. For instance, Fallon et al. (2002) used coral records of $\mathrm{Zn}, \mathrm{Pb}$, and $\mathrm{Mn}$ and David (2003) analyzed $\mathrm{Cu}, \mathrm{Mn}$, and $\mathrm{Pb}$ to investigate runoff from mines adjacent to coral reefs. In the Mesoamerican Reef, Prouty et al. (2008) found higher $\mathrm{Sb} / \mathrm{Ca}$ and $\mathrm{Cu} / \mathrm{Ca}$ ratios in coral samples collected from the Honduran sites, and suggested that these elevated concentrations may be due to copper-antimony antifouling paint used on industrial and recreational ships in the Gulf of Honduras. They also suggested that $\mathrm{Pb} / \mathrm{Ca}$ and $\mathrm{Zn} / \mathrm{Ca}$ ratios, which were elevated at Utila compared to other sites, may represent the influence of runoff from $\mathrm{El}$ Mochito mine, the largest $\mathrm{Pb} / \mathrm{Zn}$ mine in the region, via the Rio Ulua that drains into the Gulf of Honduras.

\section{Materials and Methods}

\subsection{Coral collection}

M. faveolata cores were collected from four sites on the Mesoamerican Reef: Turneffe Atoll and the Sapodilla Cayes in Belize, and Utila and Cayos Cochinos in Honduras (Fig. 2). Cores were collected vertically using a 5-cm diameter stainless steel and brass core barrel with carbide cutting teeth driven by a reversible air-powered drill. Tissue was removed using a water-pik and cores were rinsed in freshwater and air dried. Upon return to Scripps Institution of Oceanography (SIO) in La Jolla California, an 8-mm thick slab was removed from the middle of each core section using a carbide-tipped doublebladed table saw lubricated with freshwater. Slabs were x-rayed at Thornton Hospital to reveal annual density banding (Knutson et al., 1972). One core from each site was chosen to construct annual-scale time series of metal contamination, assuming local-scale homogeneity (e.g., colony and reef scale) for the given element analyzed (Prouty et al., 2008).

\subsection{Sample preparation}

Digital x-rays were printed and taped to each core to guide sampling of individual yearbands (average annual extension rate is about $8 \mathrm{~mm})$. A band saw with a thin $(\sim 0.5 \mathrm{~mm}$ wide) steel blade was used to cut annual blocks along the length of each core, from the top of one annual high-density band to the top of the next. The high-density skeleton tends to form in late summer-fall in M. faveolata in this region (Cruz-Piñón et al., 2003) and therefore each annual band represents approximately October of one year to September of the next year. 
Standard trace-element protocols for cleaning Teflon labware and preparing samples for analysis were conducted in a class-100 clean room at SIO (initial cleaning) and Woods Hole Oceanographic Institution (WHOI) in Woods Hole Massachusetts (sample analysis). Coral samples were cleaned to remove surface contamination and nonaragonitic-lattice bound phases using a method modified from Shen and Boyle (1988), Guzman and Jarvis (1996) and Bastidas and Garcia (1999). The pre-cleaning procedure involved a coarse crush, ultrasonicating three times at 10-minute intervals in quartzdistilled MilliQ $18 \mathrm{M} \Omega$ deionized water. All cleaning solutions were prepared using this ultra-clean water. Samples were next leached in $0.015 \mathrm{~N} \mathrm{HNO}_{3}$ for 20 minutes. The cleaning procedure included a sequence of oxidizing, reducing, and leaching steps with multiple rinses and ultrasonication between. Finally, samples were dried and homogenized using an agate mortar and pestle and sieved with a polypropylene sieve to assure that the particle size was less than $700 \mu \mathrm{m}$. Powdered samples were stored in acidwashed polypropylene vials until analysis at WHOI.

\subsection{Sample analysis}

Prior to analysis, approximately $1 \mathrm{mg}$ of homogenized coral aragonite powder was weighed out and dissolved in $4 \mathrm{ml} 2 \%$ Seastar ultrapure $\mathrm{HNO}_{3}$ spiked with $0.1 \mathrm{ppb}$ of an indium (In) standard using MilliQ $18 \mathrm{M} \Omega$ deionized water. Samples were dissolved in clean Teflon vials for at least 12 hours on a shaker table to maximize carbonate dissolution. This dilution yielded a Ca concentration of approximately $100 \mathrm{ppm}$ to minimize between-sample differences associated with matrix-induced mass discrimination (Rosenthal et al., 1999). The In spike served as an internal standard to facilitate corrections of instrument drift and sample matrix effects. Typical sensitivity was $\sim 1 \times 10^{6}$ counts per second per $0.1 \mathrm{ppb} \mathrm{In}$. Analytes were pipetted to $0.5 \mathrm{ml}$ Teflon vials for analysis. Trace element analysis was conducted using a Finnigan Element 2 highresolution double focusing magnetic sector-field inductively coupled plasma mass spectrometer (HR-SF-ICP-MS) at WHOI. Details regarding sample analysis can be found in Prouty et al. (2008). The limits of detection (LOD) were calculated as three times the standard deviation of the counts per second of the blanks (Zacherl et al., 2003). We calculated the average signal strength as LOD \% for our samples by computing the ratio of the average unknown and external and internal standard counts per second to the LOD for each metal (Table 2).

\subsection{Seawater samples}

Seawater samples were collected from $0.5 \mathrm{~m}$ depth for metal/Ca analysis on two transects from Cayos Cochinos towards the coastline (Fig. 3). Four samples were collected on each transect and were filtered with $0.7 \mu \mathrm{m}$ glass fiber filters to remove suspended solids. The filtrate was collected in $500 \mathrm{ml}$ acid-washed polyethelene bottles and stored refrigerated and non-acidified until analysis for metal/Ca.

Seawater samples were diluted in a 1:20 seawater: 2\% Seastar $\mathrm{HNO}_{3}$ ratio and spiked with $0.1 \mathrm{ppb}$ In. An aliquot of one sample was used to add a multi-element standard in multiple concentrations from 5-200 ppm. Analytes were pipetted to $0.5 \mathrm{ml}$ Teflon vials 
for analysis. Seawater samples were run in the following sequence: alternating single unknowns and blanks, then alternating multi-element solution standards and blanks.

3.5 Chlorophyll-a concentrations

Chlorophyll-a may reflect the influence of nutrients delivered from coastal runoff in nonupwelling regions (Furnas et al., 2005). Therefore, differences in chlorophyll-a concentrations between sites were compared using monthly-averaged satellite-derived data spanning October 1997 to October 2007, obtained from the Sea-viewing Wide Fieldof-view Sensor (Sea-WiFS) from NOAA Coastwatch (O'Reilly et al., 1998). The mapped monthly averages from June $16^{\text {th }}$-July $16^{\text {th }} 2007$ were also obtained from SeaWiFS to compare to seawater samples, which were collected during that time period.

\subsection{Data analysis}

Coral metal/Ca ratios are non-normal and no transformation satisfied the assumption of normality. Statistical tests were performed using R software (R Core Development Team, 2005). Metal/Ca ratios were tested for significant differences between sites using pairwise permutation tests. To investigate temporal trends at each site, data were smoothed using a kernel smoother with a bandwidth of 50 years, and then a linear model was fit to the smoothed data to determine if year was a significant predictor of the smoothed metal/Ca. We also binned data into decades and calculated the median value. We also tested for trends in these decadal medians by fitting a linear model to those data.

\section{Results and Discussion}

\section{Seawater}

Both transects show decreasing $\mathrm{Ba} / \mathrm{Ca}$ with distance from the coast (Fig. 3C). Transect $\mathrm{T}$, from near the mouth of the Aguan towards the west, has the steepest slope as well as the highest concentration at the second sampling site. $\mathrm{Mn} / \mathrm{Ca}$ seawater concentrations (not shown) have a similar pattern to $\mathrm{Ba} / \mathrm{Ca}$. The chlorophyll-a concentrations during the month of seawater sample collection were highest near the coast and decreased away from land (Fig. 3A), indicating that land-based runoff provides nutrients in this region needed to stimulate algal growth. Seawater $\mathrm{Ba} / \mathrm{Ca}$ and $\mathrm{Mn} / \mathrm{Ca}$ also have a similar pattern to the chlorophyll-a concentrations (Fig. 3). The pattern of decreasing $\mathrm{Ba} / \mathrm{Ca}$ and $\mathrm{Mn} / \mathrm{Ca}$ with distance from the coast and similarity with the chlorophyll-a concentrations is consistent with the idea that these metal/Ca ratios represent fluvial runoff enriched in terrestrial sediment and nutrients.

\section{Coral samples}

Overall differences in metal concentrations between sites through time preserve the same rank order as in the replicate core-top samples observed by Prouty et al. (2008), with Turneffe consistently having the lowest levels of metals (Fig. 4,5, Table 3). Sapodilla Cayes has the highest influence from terrestrial runoff based on $\mathrm{Ba} / \mathrm{Ca}$ ratios, followed by Cayos Cochinos, Utila, and Turneffe Atoll. Sapodilla Cayes also has the highest levels of $\mathrm{Sb} / \mathrm{Ca}$ compared to all other sites. For several metals, there is no statistical difference between the Sapodilla Cayes and Cayos Cochinos, but both of these sites are enriched in $\mathrm{Cr} / \mathrm{Ca}, \mathrm{Cu} / \mathrm{Ca}, \mathrm{Mn} / \mathrm{Ca}, \mathrm{Pb} / \mathrm{Ca}$, and $\mathrm{Zn} / \mathrm{Ca}$ compared with Utila and Turneffe, which are not significantly different from one another for $\mathrm{Pb} / \mathrm{Ca}$ and $\mathrm{Zn} / \mathrm{Ca}$ (Table 4). These 
rankings, with higher runoff affecting the sites in the south (Sapodilla, Utila, and Cayos Cochinos), and those closest to land (Sapodilla and Cayos Cochinos) agree with average chlorophyll-a concentrations (Fig. 5), and also the expected pattern of the highest metal/Ca ratios at sites closest to the main sources of runoff in Honduras (Burke and Sugg, 2006; Chérubin et al., 2008).

Metals that have significant $(\mathrm{p}<0.05)$ increasing baseline trends, based on both smoothed and binned data, are noted in Table $5 . \mathrm{Ba} / \mathrm{Ca}$ increases over time at all sites, indicating that sediment delivery to the reef has increased over the past 100-150 years, and this increase appears to have been steady (Fig. 4), similar to increases in land use and development adjacent to the reef (Fig. 1). All other metals have increasing trends at one or more sites. However, although the rank difference between sites is maintained, not all metals have increasing trends. Note that the large peaks in some metals throughout the records may stem from actual large pulses of contaminated runoff, sampling intermittent particles enriched in a particular metal, or analytical noise associated with high limits of detection in relation to the metal abundance. Therefore, instead of interpreting individual peaks, we focus our interpretation on the trends of the metal baselines calculated from either smoothed or binned data as these time-series are more robust to statistical analysis (Table 5 and Fig. 4b).

Records of river discharge and rainfall for the region are somewhat sparse in both space and time. Monthly average river discharge from gauge stations along three major rivers in Honduras (the Ulua, Chamelecon, and Aguan) are plotted in Fig. 6 (see Fig. 7 for station gauge locations). The longest rainfall records for the region, from Belize City and Guatemala City, are also plotted for comparison (Fig. 6). A thorough investigation of trends in the climatology and hydrology of this region is beyond the scope of this study, however simple linear regressions through each of these records indicates a lack of consistent trends: about half of the river discharge records have an increasing trend, while half have a decreasing trend. Similarly, rainfall at Guatemala City has a decreasing trend, while that at Belize City has an increasing trend. However, the large amount of annual rainfall (regional average $\sim 200 \mathrm{~cm}$ ), and relatively small interannual variability (standard deviation $\sim 30 \mathrm{~cm}$ ) suggest that these trends are probably insignificant. Our metal/Ca records may instead be more robust measures of overall runoff affecting the Mesoamerican Reef, as these records average runoff impacts over both time and space, as opposed to the river discharge and rainfall measurements which may contain biases due to unrepresentative catchment behavior.

Chérubin et al. (2008) modeled the advection of runoff plumes across the Mesoamerican Reef. They found that runoff mainly originated from Honduras, but plumes were advected in a counterclockwise gyre around the reef. This mixing of runoff over the reef may explain the similar trends in $\mathrm{Ba} / \mathrm{Ca}$ across sites: the runoff is all originating from the same location, but the signal is diluted with greater distance from the main source: the Gulf of Honduras. The other metals may be more affected by localized conditions, such as scavenging by particles or biological activity. 
Increasing runoff may be negatively affecting corals at the Sapodilla Cayes, which experiences the highest levels of sedimentation, according to the relative $\mathrm{Ba} / \mathrm{Ca}$ concentrations. Long-term records compiled from multiple coral colonies from each site show declining growth rates at the Sapodilla Cayes beginning in the 1970's (Carilli et al. in press). In addition, by the time cores were collected in 2006 and 2007, corals at this site had not yet recovered from growth suppression due to a severe bleaching event in 1998 (Carilli et al. 2009). These growth effects reflect sublethal chronic stress, probably due to the negative impacts of increasing runoff at this site. While these studies investigated Montastraea faveolata corals, increasing runoff is expected to negatively influence other massive corals or those less resistant to sediment stress as well.

\section{Conclusions}

These century-scale coral geochemical records indicate that as development and agriculture expand in Honduras, Guatemala, and Belize, the adjacent reef system is experiencing higher levels of runoff. In addition, these records confirm that runoff impacts are concentrated near the main input sources in the south. The Sapodilla Cayes and Cayos Cochinos, the two sites that experience the highest runoff impacts, are both marine reserves. However, designation as a marine reserve does not necessarily influence the amount of runoff entering the reserve. Given previous work showing riverreef connectivity in the Meso-American Region (Andréfouët et al., 2002; Chérubin et al. 2008; Paris and Chérubin, 2008; Soto et al., 2009) and the deleterious effects on corals from sedimentation and heavy metals (Rogers, 1990; Peters et al., 1997), we suggest that efforts should be focused on reducing runoff from the land into these marine protected areas. Examples of measures to reduce the impact of land-based runoff include replanting mangroves to trap sediment and attached pollutants at the coast, maintaining vegetative barriers along waterways to prevent eroded material from entering the drainage system, and terracing steep hillsides to reduce soil erosion.

Although more distal sites like Turneffe and Utila experience lower overall amounts of runoff, the steady increase in land development and associated runoff across the entire reef shows that without changes in land use practices, these reefs will likely become more degraded in the future. Because local impacts such as sedimentation and nutrient loading likely reduce a coral's thermal tolerance, the combination of increasing runoff and water temperatures is likely to be devastating for the future of coral reefs (Knowlton and Jackson, 2008; Wooldridge, 2009). Therefore, reducing local impacts such as runoff may increase the likelihood of corals surviving into the future.

Acknowledgements: The authors wish to thank M. Roldan at Thornton Hospital for X-raying the cores, and M. Carilli, B. Erisman, E. Kisfaludy, J. Shrives, A. Stumpf, and A. Young for help in the field. A. Young also helped make the maps. We thank P. Castillo for use of his clean-room for preparing samples, K. Vyas for help cleaning coral samples, and S. Birdwhistell for analytical help. We thank the Belizean and Honduran governments for supplying permits and World Wildlife Fund Belize, The University of Belize, Reef Conservation International, The Honduran Coral Reef Foundation, and Operation Wallacea for logistical support. This research was supported by funds from the PADI Foundation, B. Katz, two anonymous donors and the Edna Bailey Sussman Foundation to J.C.

\section{References}


Abram, N., Gagan, M.K., McCulloch, M.T., Chappell, J., Hantoro, W.S., 2003. Coral reef death during the 1997 Indian Ocean Dipole linked to Indonesian wildfires. Science 301, 952-955.

Alibert, C., Kinsley, L., Fallon, S.J., McCulloch, M.T., Berkelmans, R., McAllister, F., 2003. Source of trace element variability in Great Barrier Reef corals affected by the Burdekin flood plumes. Geochim. Cosmochim. Acta 67, 231-246.

Andréfouët, S., Mumby, P.J., McField, M., Hu, C., Muller-Karger, F.E., 2002. Revisiting coral reef connectivity. Coral Reefs 21, 43-48.

Bastidas, C., Garcia, E., 1999. Metal content of the reef coral Porites astreoides: an evaluation of river influence and 35 years of chronology. Mar. Poll. Bull. 38, 899-907.

Burke, L., Sugg, Z., 2006. Hydrologic Modeling of Watersheds Discharging Adjacent to the Mesoamerican Reef. (World Resources Institute, Washington, DC).

Carilli, J.E., Norris, R.D., Black, B., Walsh, S.W., McField, M., in press, Global Change Biology. Century-scale records of coral growth rates indicate that local stressors reduce coral thermal tolerance threshold.

Carilli, J.E., Norris, R.D., Black, B., Walsh, S.W., McField, M., 2009. Local stressors reduce coral resilience to bleaching. PLoS ONE 4, e6324.

Chérubin, L., Kuchinke, C.P., Paris, C.B., 2008. Ocean circulation and terrestrial runoff dynamics in the Mesoamerican region from spectral optimization of SeaWiFS data and a high resolution simulation. Coral Reefs 27, 503-519.

Cobb, K., Charles, C.D., Cheng, H., Edwards, R.L., 2003. El Nino/Southern Oscillation and the tropical Pacific climate during the last millennium. Nature 424, 271-276.

Cohen, A., McConnaughey, T.A., 2003. Geochemical perspectives on coral mineralization. Rev. Miner. Geochem. 54, 151-187.

Correge, T., 2006. Monitoring of terrestrial input by massive corals. J. Geochem. Explor. $88,380-383$.

Cruz-Piñón, G., Carricart-Ganivet, J.P., Espinoza-Avalos, J., 2003. Monthly skeletal extension rates of the hermatypic corals Montastrea annularis and Montastrea faveolata: biological and environmental controls. Mar. Biol. 143, 491-500.

David, C., 2003. Heavy metal concentrations in growth bands of corals: a record of mine tailings input through time (Marinduque Island, Philippines). Mar. Poll. Bull. 46, 187196.

Dodge, R., Vaisnys, J.R., 1977. Coral populations and growth patterns: Responses to sedimentation and turbidity associated with dredging. J. Mar. Res. 35, 715-730. 
Dunbar, R.B., Wellington, G.M., Colgan, M.W., Glynn P.W., 1994. Eastern Pacific sea surface temperature since 1600 A.D.: The $\delta^{18} \mathrm{O}$ record of climate variability in Galápagos corals. Paleoceanog. 9, 291-316.

Fallon, S., White, J.C., McCulloch, M.T., 2002. Porites corals as recorders of mining and environmental impacts: Misima Island, Papua New Guinea. Geochim. Cosmochim. Acta $66,45-62$.

Fleitmann, D., Dunbar, R.B., McCulloch, M., Mudelsee, M., Vuille, M., McClanahan, T.R., Cole, J.E., Eggins, S., 2007. East African soil erosion recorded in a 300 year old coral colony from Kenya. Geophys. Res. Lett. 34, L04401.

Foley, J.A., DeFries, R., Asner, G.P., Barford, C., Bonan, G., Carpenter, S.R., Chapin, F.S., Coe, M.T., Daily, G.C.Gibbs, H.K., 2005. Global consequences of land use. Science $309,570-574$.

Food and Agriculture Organization of the United Nations, 2004. United Nations Environment Program.

Furnas, M., Mitchell, A., Skuza, M., Brodie, J., 2005. In the other 90\%: phytoplankton responses to enhanced nutrient availability in the Great Barrier Reef Lagoon. Mar. Poll, Bull. 51, 253-265.

Guzman, H., Jarvis, K.E., 1996. Vanadium century record from Caribbean reef corals: a tracer of oil pollution in Panama. Ambio 35, 523-526.

Hall, C., Brignoli, H.P., 2003. Historical atlas of Central America. University of Oklahoma Press, Norman, Oklahoma.

Hanna, R., Muir, G.L., 1990. Red Sea corals as biomonitors of trace metal pollution. Environ. Monit. Assess. 14, 211-222.

Kojis, B., Quinn, N.J., 1984. Seasonal and depth variation in fecundity of Acropora palifera at two reefs in Papua New Guinea. Coral Reefs 3, 165-172.

Kok, K., 2004. The role of population in understanding Honduran land use patters. J. Environ. Manage. 72, 73-89.

Knowlton, N., Jackson, J.B.C., 2008. Shifting baselines, local impacts, and global change on coral reefs. PLOS Biology 6, 215-220.

Knutson, D., Buddemeier, R.W., Smith, S.V., 1972. Coral chronometers: seasonal growth bands in reef corals. Science 177, 270-272. 
Lewis, S., Sheilds, G.A., Kamber, B.S., Lough, J.M., 2007. A multi-trace element coral record of land-use changes in the Burdekin River catchment, NE Australia. Palaeogeog. Palaeoclimatol. Palaeoecol. 246, 471-487.

Marion, G., Dunbar, R.B., Mucciarone, D.A., Kremer, J.N., Lansing, J.S. Arthawiguna, A., 2005. Coral skeletal $\delta^{15} \mathrm{~N}$ reveals isotopic traces of an agricultural revolution. Mar. Poll. Bull. 50, 931-944.

Matson, P., Parton, W.J., Power, A.G., Swift, M.J., 1997. Agricultural intensification and ecosystem properties. Science 277, 504-509.

McClanahan, T., Aronson, R.B., Precht, W.F., Muthiga, N.A., 1999. Fleshy algae dominate remote coral reefs of Belize. Coral Reefs 18, 61-62.

McCulloch, M., Fallon, S., Wyndham, T., Hendy, E., Lough, J., Barnes, D., 2003. Coral record of increased sediment flux to the inner Great Barrier Reef since European settlement. Nature 421, 727-730.

McField, M., 1999. Coral response during and after mass bleaching in Belize. Bull. Mar. Sci. 64, 155-172.

Negri, A., Heyward, A.J., 2001. Inhibition of coral fertilisation and larval metamorphosis by tributyltin and copper. Mar. Environ. Res. 51, 17-27.

O'Reilly, J., Maritorena, S., Mitchell, B.G., Siegel, D.A., Carder, K.L., Garver, S.A., Kahru, M., McClain, C., 1998. Ocean color chlorophyll algorithms for SeaWiFS. J. Geophys. Res. 103, 24,937-24,953.

Oxford Latin American Economic History Database, 2009. Oxford University. http://oxlad.qeh.ox.ac.uk/index.php.

Paris, C., Cherubin, L.M., 2008. River-reef connectivity in the Meso-American region. Coral Reefs 27, 773-781.

Peters, E., Gassman, N.J., Firman, J.C., Richmon, R.H., Power, E.A., 1997. Ecotoxicology of tropical marine ecosystems. Environ. Toxicol. Chem. 16, 12-40.

Prouty, N., Hughen, K.A., Carilli, J., 2008. Geochemical signature of land-based activities in Caribbean coral surface samples. Coral Reefs 27, 727-742.

R Development Core Team, 2005. R: A language and environment for statistical computing. R Foundation for Statistical Computing, Vienna, Austria. ISBN 3-900051-070 , http://www.Rproject.org. 
Ramos, A.A., Inoue, Y., Ohde, S., 2004. Metal contents in Porites corals: Anthropogenic input of river run-off into a coral reef from an urbanized area, Okinawa. Mar. Poll. Bull. 48, 281-294.

Richmond, R. H., 1993. Coral reefs: present problems and future concerns resulting from anthropogenic disturbance. Amer. Zool. 33, 524-536.

Rogers, C., 1990. Responses to coral reefs and reef organisms to sedimentation. Mar. Ecol. Prog. Ser. 62, 185-202.

Rosenthal, Y., Field, M.P., Sherrel, R.M., 1999. Precise determination of element/calcium ratios in calcareous samples using sector field inductively coupled plasma mass spectrometry. Anal. Chem. 71, 3248-3253.

Runnalls, L., and Coleman, M.L., 2003. Record of natural and anthropogenic changes in reef environments (Barbados West Indies) using laser ablation ICP-MS and sclerochronology on coral cores. Coral Reefs 22, 416-426.

Shen, G., Boyle, E.A., 1988. Determination of lead, cadmium, and other trace metals in annually-banded corals. Chem. Geol. 67, 47-62.

Smith, S.V., Buddemeier, R.W., Redalje, R.C., Houck, J.E., 1979. Strontium-calcium thermometry in coral skeletons. Science 204, 404-407.

Soto, I., Andréfouët, S., Hu, C., Muller-Karger, F.E., Wall, C.C., Sheng, J., Hatcher, B.G., 2009. Physical connectivity in the Mesoamerican Barrier Reef System inferred from 9 years of ocean color observations. Coral Reefs doi: 10.1007/s00338-009-0465-0.

Thattai, D., Kjerfve, B., Heyman, W.D., 2003. Hydrometeorology and variability of water discharge and sediment load in the inner Gulf of Honduras, western Caribbean. J. Hydromet. 4, 985-995.

United Nations 2006. Demographic Yearbook, Historical Supplement.

Wooldridge, S., 2009. Water quality and coral bleaching thresholds: Formalising the linkage for the inshore reefs of the Great Barrier Reef, Australia. Mar. Poll. Bull. 58, 745751.

Zacherl, D., Manrìquez, P.H., Paradis, G., Day, R.W., Castilla, J.C., Warner, R.R., Lea, D.W., Gaines, S.D., 2003. Trace elemental fingerprinting of gastropod statoliths to study larval dispersal trajectories. Mar. Ecol. Prog. Ser. 248, 297-303. 


\section{Figures}

Figure 1: Time series of population and development in Guatemala, Honduras, and Belize. (A) Population of each country, from the United Nations (2006) (thick line) and the Oxford Latin American Economic History Database (2009) (thin line). (B) The amount of fertilizer used in each country. (C) The amount of land used for agriculture in each country. (B) and (C) show data from the Food and Agriculture Organization of the United Nations (2004). (D) Labeled gray bars show approximate time period during which a particular form of development or land use was occurring in the region. These time periods are from Hall and Brignoli (2003).

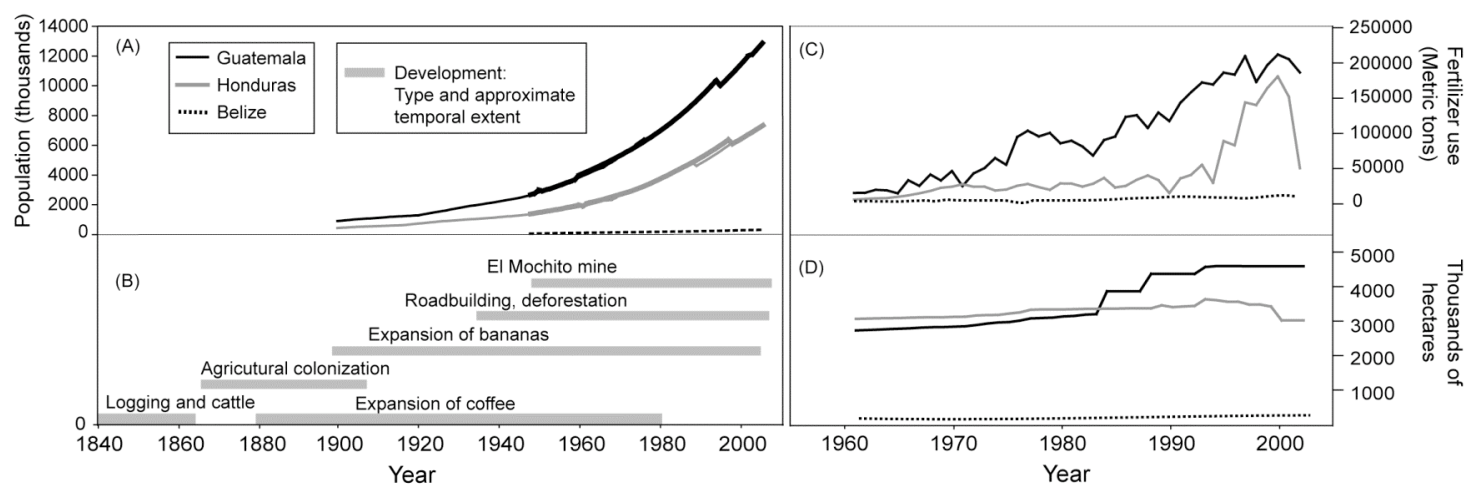


Figure 2: Topographic map of the Mesoamerican Reef region. Reef areas are in dark gray. Coral collection sites are marked with black circles. $\mathrm{T}=$ Turneffe Atoll, $\mathrm{S}=$ Sapodilla Cayes, $\mathrm{U}=$ Utila, and $\mathrm{C}=$ Cayos Cochinos. Rivers are denoted with black lines and named in italics. Landmarks are denoted with black squares. $\mathrm{BC}=$ Belize City, $\mathrm{PB}=$ Puerto Barrios, $\mathrm{SPS}=$ San Pedro Sula, $\mathrm{MM}=\mathrm{El}$ Mochito Mine, $\mathrm{LC}=$ La Ceiba.

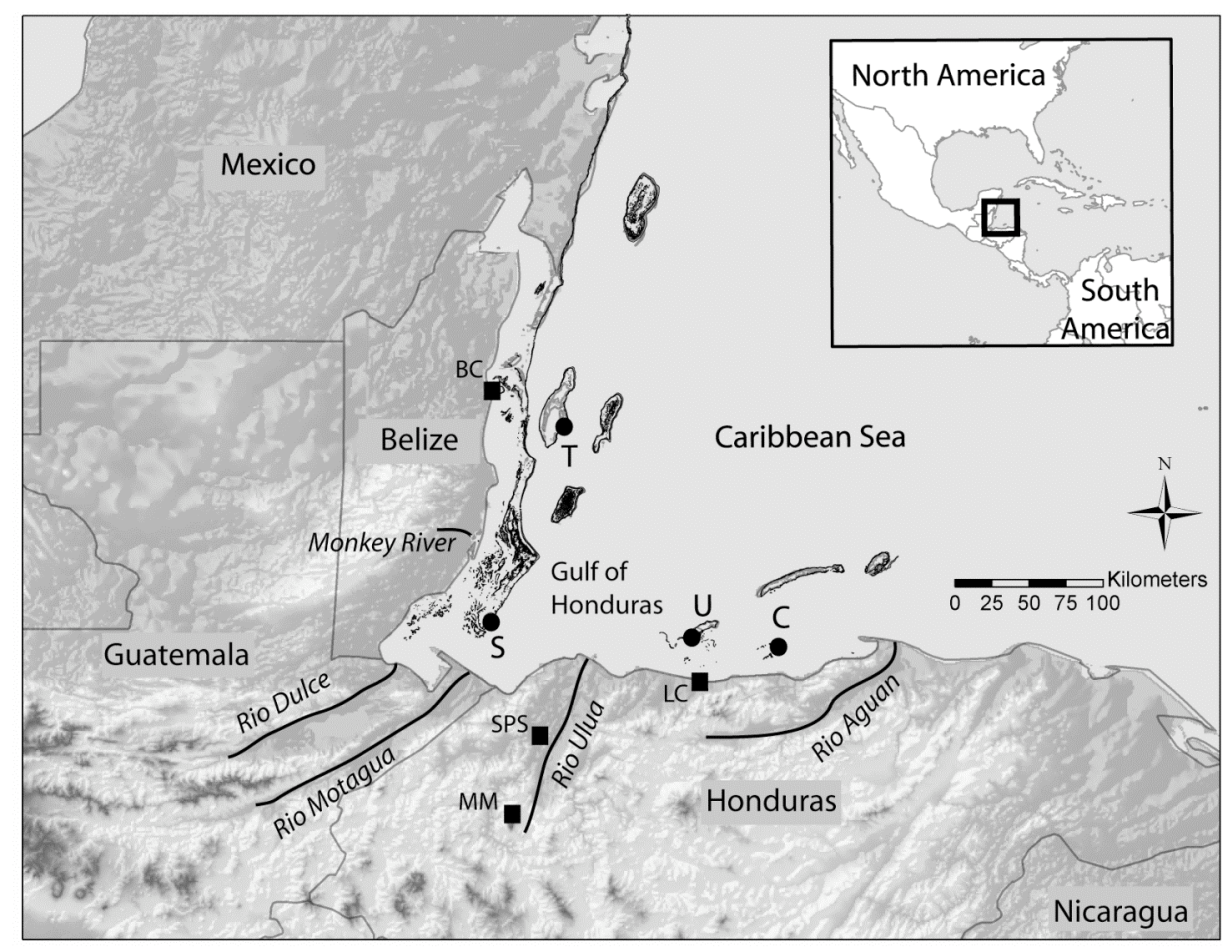


Figure 3: Comparison between SeaWiFS-derived chlorophyll-a and seawater $\mathrm{Ba} / \mathrm{Ca}$ measurements. (A) Monthly composite chlorophyll-a from SeaWiFS on the $16^{\text {th }}$ of July, 2007, along with seawater sampling sites on two transects, C and T, between Cayos Cochinos and the Honduran mainland. Seawater samples were collected on the $13^{\text {th }}$ and $14^{\text {th }}$ of July, 2007. (B) Contour plot of $\mathrm{Ba} / \mathrm{Ca}$.(C) $\mathrm{Ba} / \mathrm{Ca}$ from all eight seawater sampling sites on transects $\mathrm{C}$ and $\mathrm{T}$.
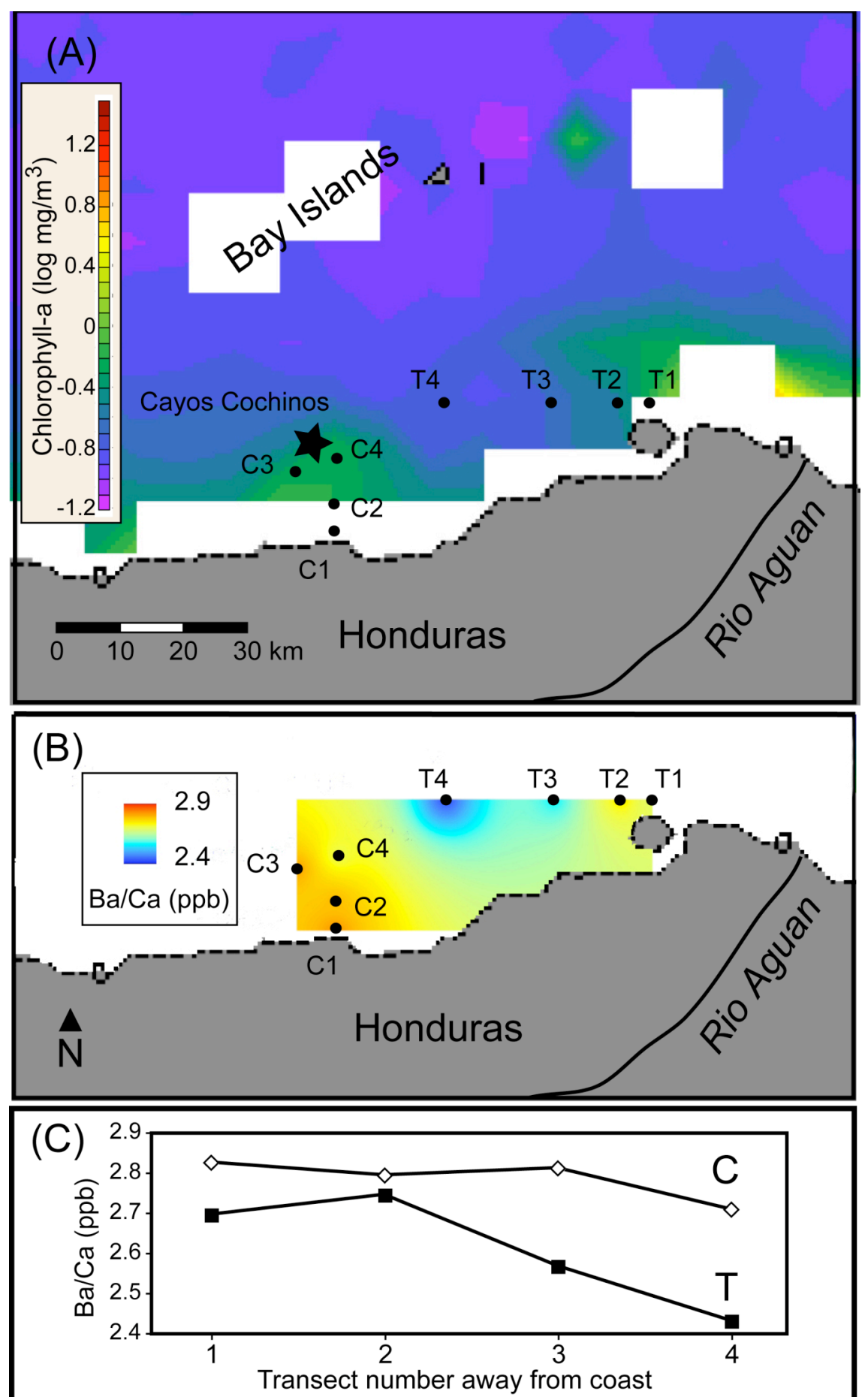
Figure 4: Long term records of metals. (A) Annual metal $/ \mathrm{Ca}$ at each site in $\mu \mathrm{mol} / \mathrm{mol}$. (B) Medians of decadal bins of metal $/ \mathrm{Ca}$ at each site in $\mu \mathrm{mol} / \mathrm{mol}$. Note different scales on axes.
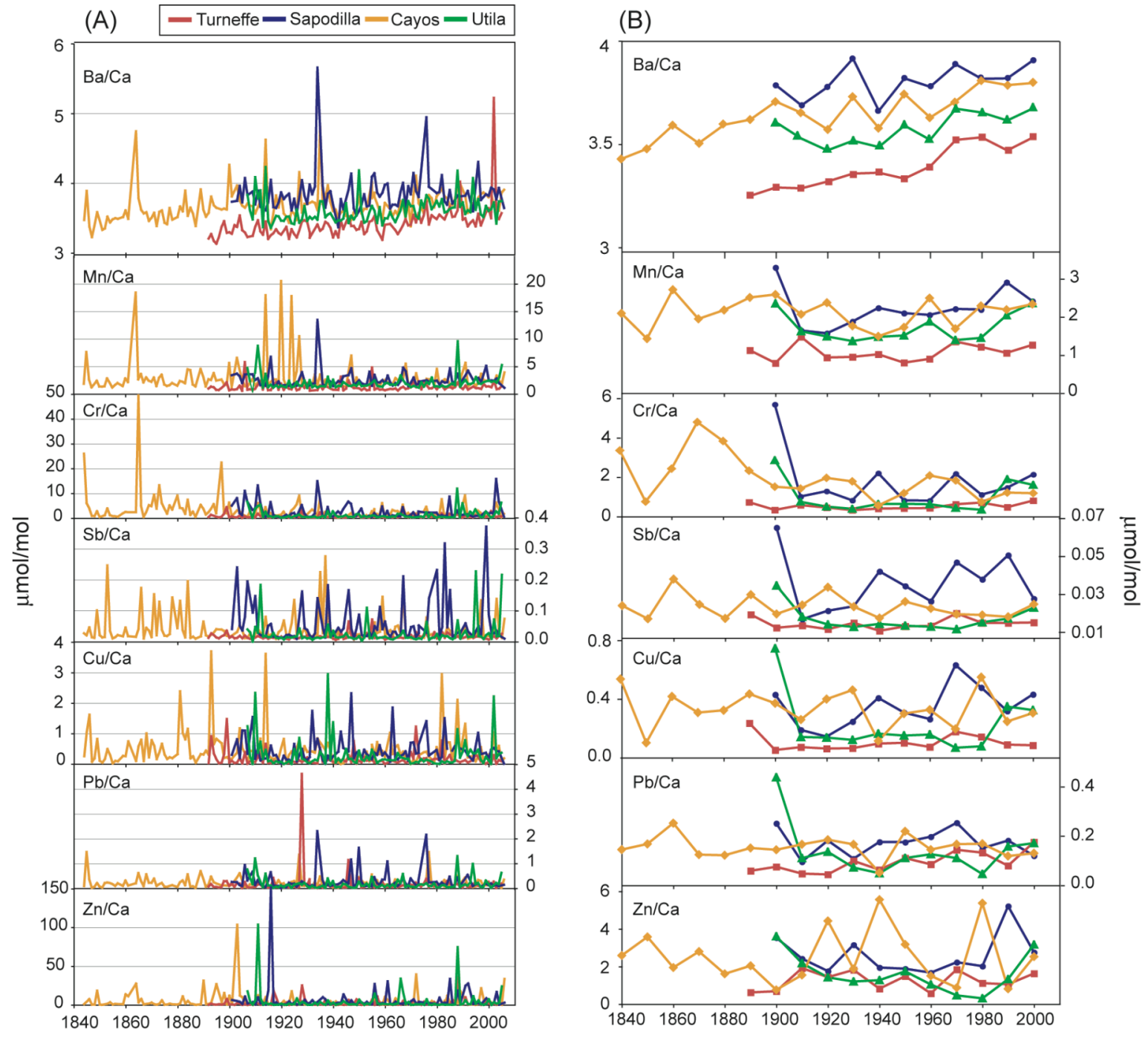
Figure 5: Boxplots of metal/Ca at each site over the common length of each record (1907-2005) as well as chlorophyll-a from SeaWiFS. Note that outliers have not been plotted.

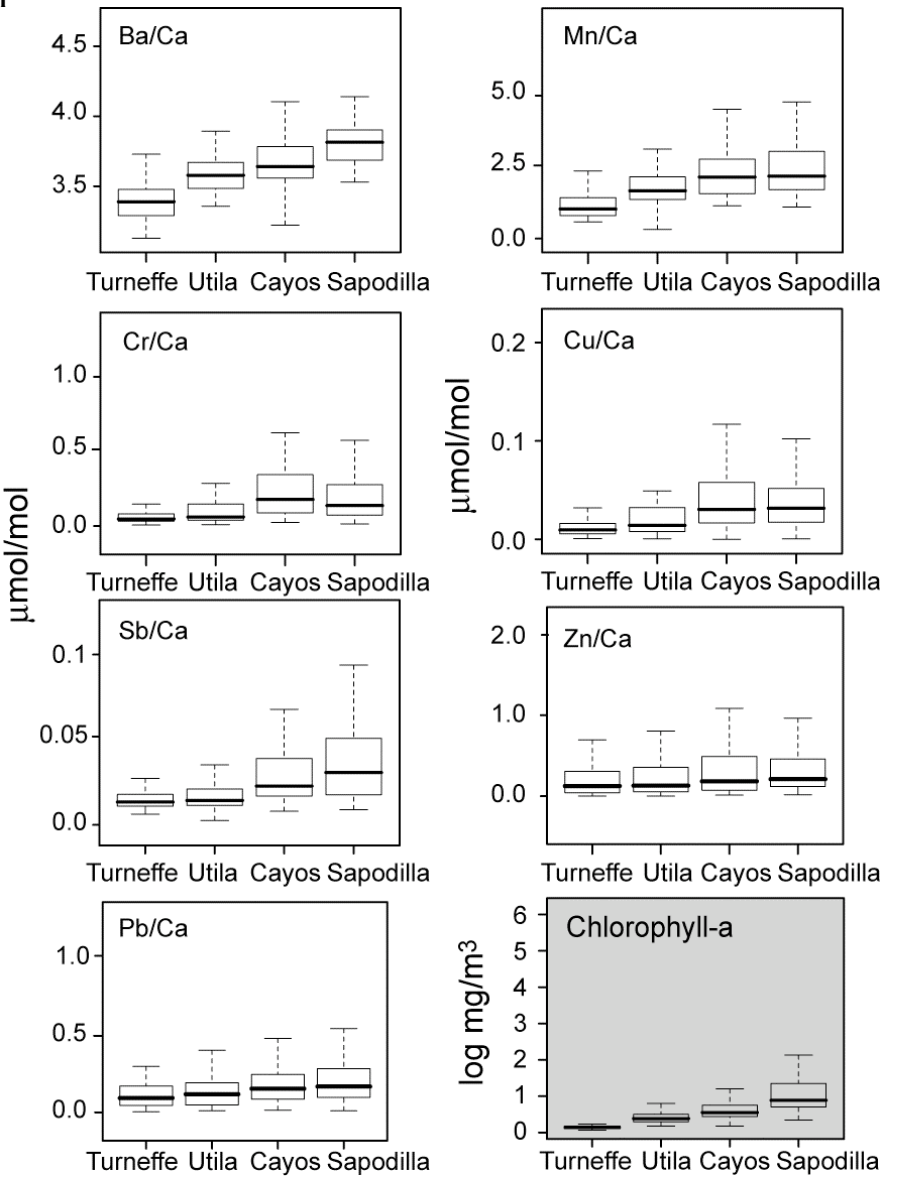


Figure 6: Monthly average river discharge (cubic meters/second) at various gauging stations on three major rivers in Honduras, the Ulua, Chamelecon, and Aguan, provided by C. Reich of the United States Geological Survey. Note that the station gauges were washed out due to Hurricane Mitch in 1998. Monthly average rainfall is also plotted for Belize City and Guatemala City, which have the longest $\sim$ continuous records in the region, obtained from the World Monthly Surface Station Climatology supplied by the Data Support Section of the Computational and Information Systems Laboratory at the National Center for Atmospheric Research. Note the different scales on each y-axis.

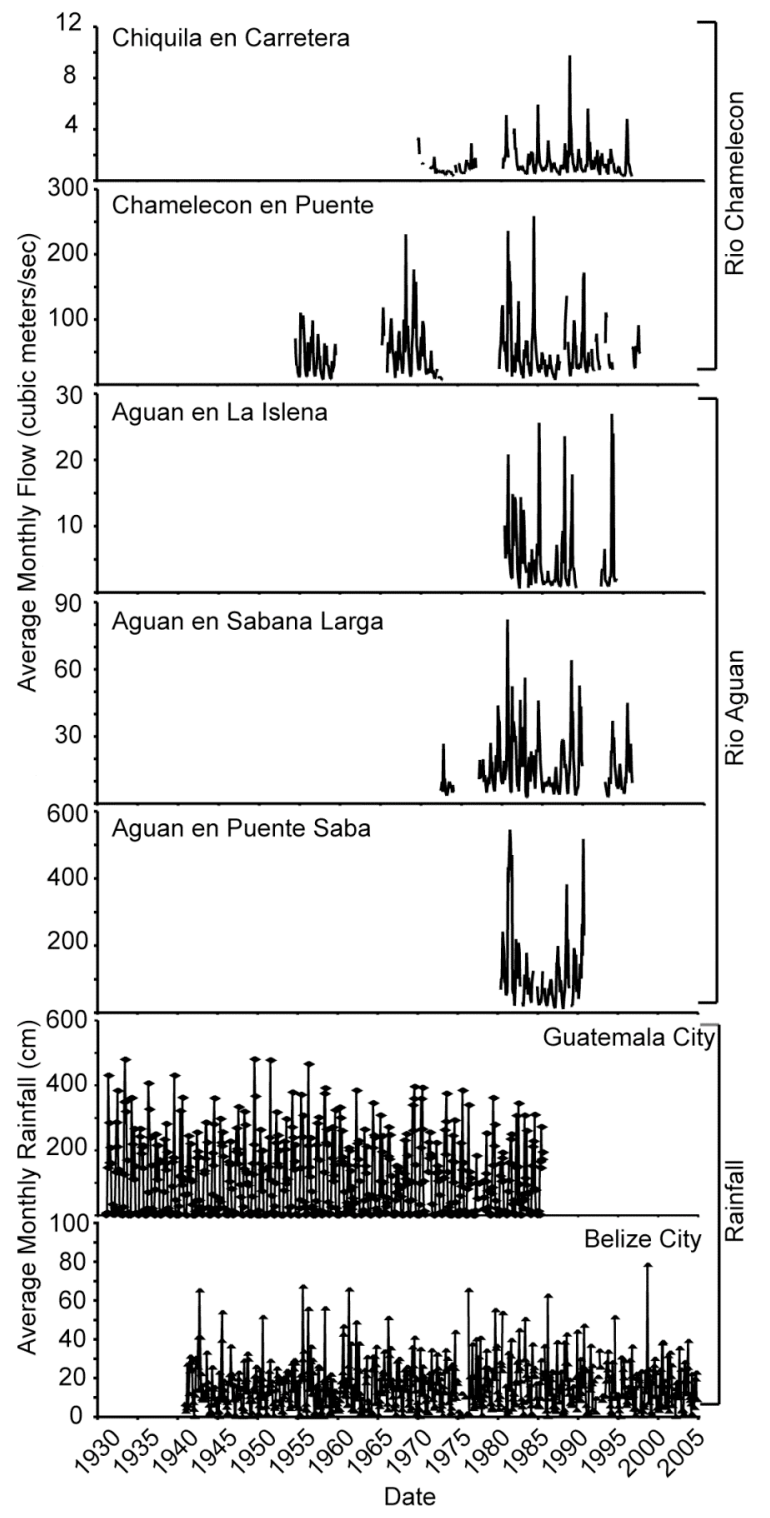

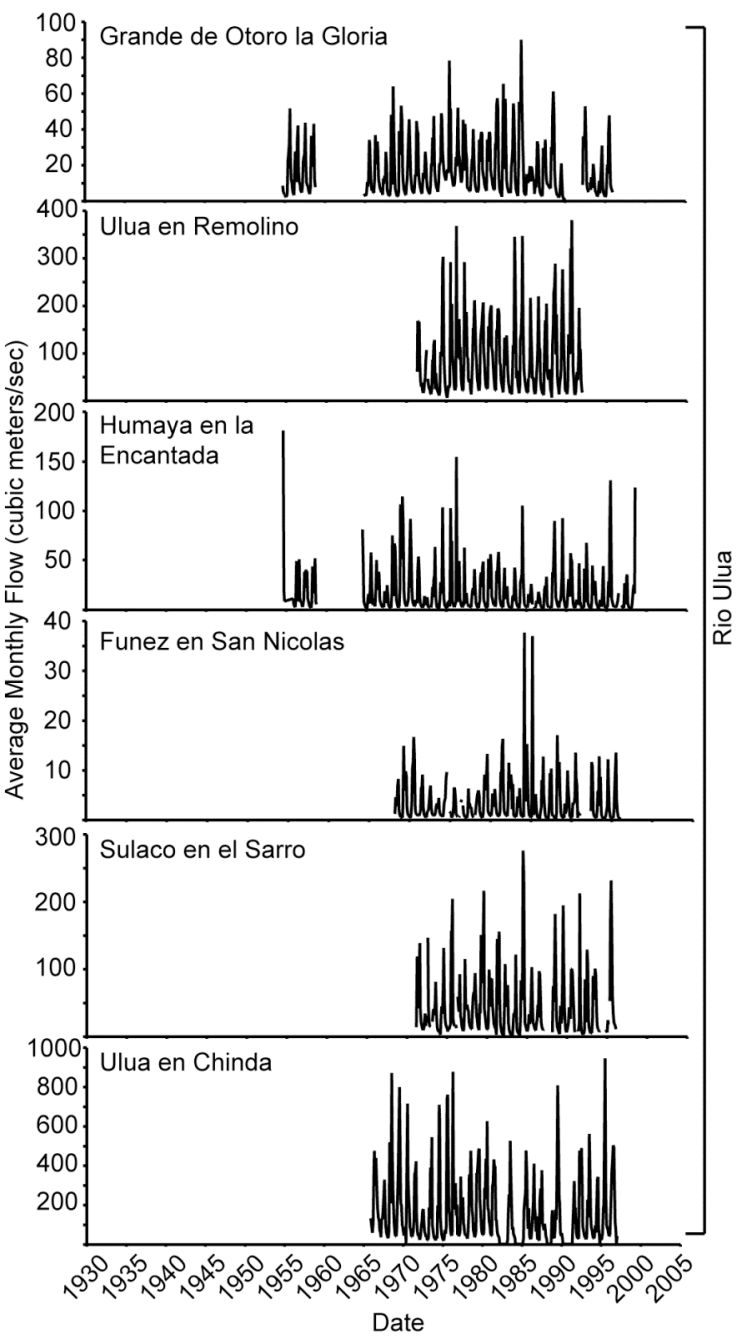


Figure 7: Map of locations of river gauging stations for records plotted in Fig. 6. Also shown are the locations corals were collected as in Fig. 2.

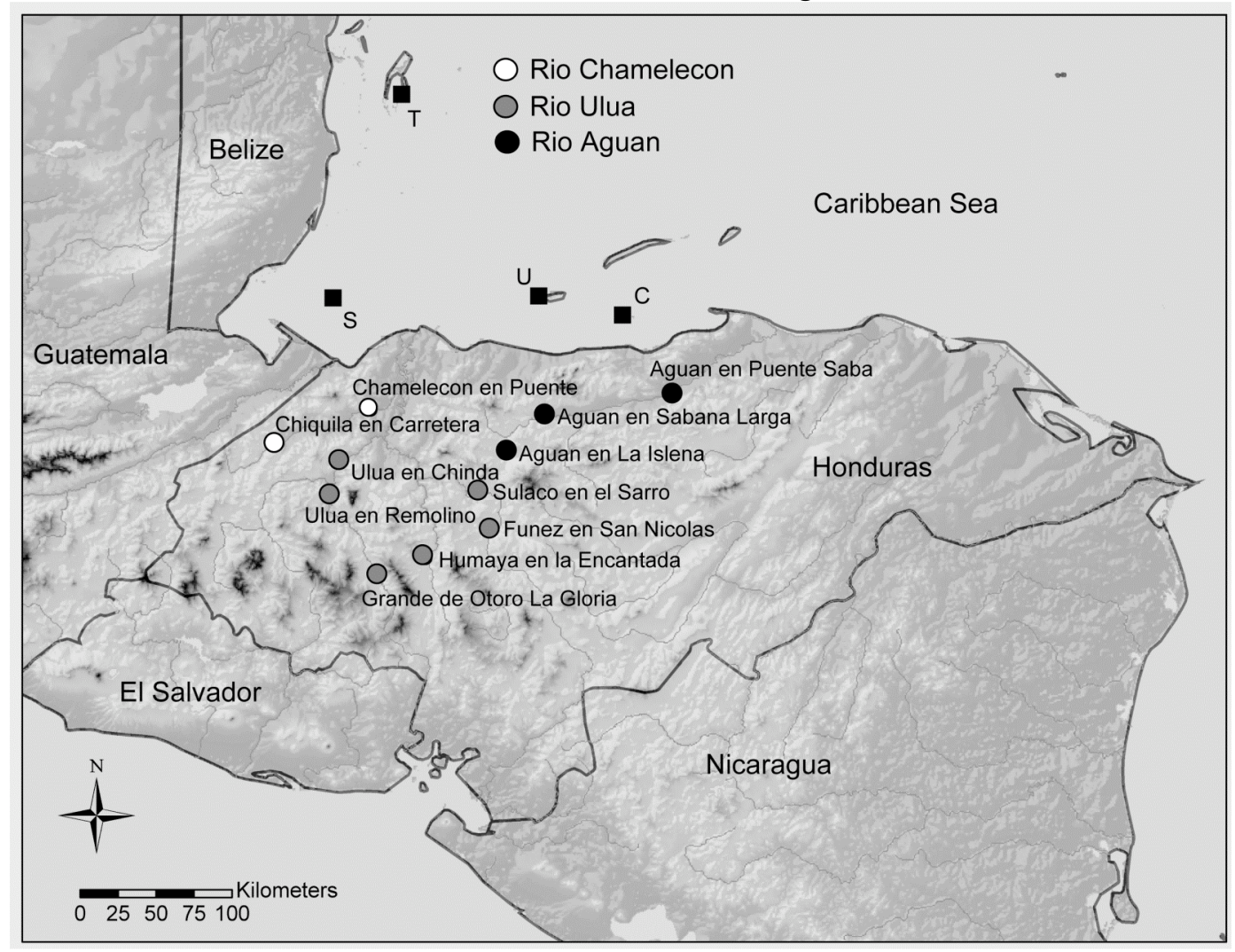

\section{Tables}

Table 1: Standard error for each metal/Ca ratio.

\begin{tabular}{ll}
\hline Metal $/ C a$ & Standard Error \pm \\
\hline \hline $\mathrm{Ba} / \mathrm{Ca}$ & $3.15 \times 10^{5}$ \\
$\mathrm{Cr} / \mathrm{Ca}$ & $8.18 \times 10^{5}$ \\
$\mathrm{Cu} / \mathrm{Ca}$ & $5.17 \times 10^{6}$ \\
$\mathrm{Mn} / \mathrm{Ca}$ & $5.05 \times 10^{5}$ \\
$\mathrm{~Pb} / \mathrm{Ca}$ & $3.94 \times 10^{6}$ \\
$\mathrm{Sb} / \mathrm{Ca}$ & $1.28 \times 10^{6}$ \\
$\mathrm{Zn} / \mathrm{Ca}$ & $2.43 \times 10^{5}$ \\
\hline
\end{tabular}


Table 2: The average signal strength of each element expressed as a percentage of the limits of detection.

\begin{tabular}{ll}
\hline Element & LOD \% \\
\hline \hline $\mathrm{Ba}$ & 45,497 \\
$\mathrm{Ca}$ & 973,789 \\
$\mathrm{Cr}$ & 912 \\
$\mathrm{Cu}$ & 1,350 \\
$\mathrm{Mn}$ & 3,622 \\
$\mathrm{~Pb}$ & 2,051 \\
$\mathrm{Sb}$ & 907 \\
$\mathrm{Zn}$ & 3,020 \\
\hline
\end{tabular}

Table 3: Long-term average and standard deviation of each metal/Ca from each site in $\mu \mathrm{mol} / \mathrm{mol}$ over the common time period 1907-2005.

\begin{tabular}{ccccc}
\hline $\begin{array}{c}\text { Site } \\
\mathrm{Metal} / \mathrm{Ca}\end{array}$ & $\begin{array}{c}\text { Turneffe } \\
\text { Average, } \\
\sigma( \pm)\end{array}$ & $\begin{array}{c}\text { Utila } \\
\text { Average, } \\
\sigma( \pm)\end{array}$ & $\begin{array}{c}\text { Cayos Cochinos } \\
\text { Average, } \\
\sigma( \pm)\end{array}$ & $\begin{array}{c}\text { Sapodilla } \\
\text { Average, } \\
\sigma( \pm)\end{array}$ \\
\hline \hline $\mathrm{Ba} / \mathrm{Ca}$ & 3.43, & 3.60, & 3.71, & 3.84, \\
& 0.226 & 0.172 & 0.209 & 0.281 \\
$\mathrm{Mn} / \mathrm{Ca}$ & 1.22, & 2.03, & 2.87, & 2.56, \\
& 0.626 & 1.302 & 3.143 & 1.550 \\
$\mathrm{Cr} / \mathrm{Ca}$ & 0.69, & 1.26, & 2.01, & 2.40, \\
& 0.586 & 1.720 & 1.925 & 2.956 \\
$\mathrm{Sb} / \mathrm{Ca}$ & $1.58 \mathrm{E}-02$, & $2.49 \mathrm{E}-02$, & $3.73 \mathrm{E}-02$, & $5.59 \mathrm{E}-02$, \\
& $9.55 E-03$ & $3.64 E-02$ & $4.39 E-02$ & $6.75 E-02$ \\
$\mathrm{Cu} / \mathrm{Ca}$ & 0.14, & 0.30, & 0.44, & 0.44, \\
& 0.180 & 0.478 & 0.527 & 0.422 \\
$\mathrm{Zn} / \mathrm{Ca}$ & 3.05, & 5.25, & 3.81, & 6.53, \\
& 5.2 & 14.4 & 5.6 & 17.4 \\
$\mathrm{~Pb} / \mathrm{Ca}$ & 0.17, & 0.18, & 0.20, & 0.28, \\
& 0.478 & 0.227 & 0.212 & 0.390 \\
\hline
\end{tabular}


Table 4: Metal/Ca ratios that are significantly different $(\mathrm{p}<0.05)$ between sites as tested using pairwise permutation tests.

\begin{tabular}{ccccc}
\hline Sites & Turneffe & Utila & $\begin{array}{c}\text { Cayos } \\
\text { Cochinos }\end{array}$ & Sapodilla \\
\hline \hline \multirow{2}{*}{ Turneffe } & -- & $\mathrm{Ba}, \mathrm{Cr}, \mathrm{Cu}$, & $\mathrm{Ba}, \mathrm{Cr}, \mathrm{Cu}$, & $\mathrm{Ba}, \mathrm{Cr}, \mathrm{Cu}$, \\
& $\mathrm{Mn}, \mathrm{Sb}, \mathrm{Pb}, \mathrm{Sb}$, & $\mathrm{Mn}, \mathrm{Pb}, \mathrm{Sb}$, \\
& & $\mathrm{Zn}$ & $\mathrm{Zn}$ \\
Utila & -- & $\mathrm{Ba}, \mathrm{Cr}, \mathrm{Cu}$, & $\mathrm{Ba}, \mathrm{Cr}, \mathrm{Cu}$, \\
& & & $\mathrm{Mn}, \mathrm{Pb}, \mathrm{Sb}$ & $\mathrm{Mn}, \mathrm{Sb}$, \\
Cayos & & & $\mathrm{Zn}$ \\
Cochinos & & & $\mathrm{Ba}, \mathrm{Sb}$ \\
& & & & \\
\hline
\end{tabular}

Table 5: Metal/Ca ratios that have significant $(\mathrm{p}<0.05)$ increasing trends at each site. "Median" data indicates metals for which trends are significant as tested by fitting a linear model to the medians of data binned by decade. For Sapodilla and Utila, the decade 1900 was excluded for all tests except $\mathrm{Ba} / \mathrm{Ca}$ because it was influenced by anomalous high values. "Smoothed" data indicates metals for which trends were significant as tested by smoothing data with a kernel filter (bandwidth 50) and fitting with a linear model.

\begin{tabular}{ccccc}
\hline Site & Turneffe & Utila & Cayos Cochinos & Sapodilla \\
\hline \hline Median & $\mathrm{Ba}, \mathrm{Pb}$ & $\mathrm{Ba}, \mathrm{Mn} *$ & $\mathrm{Ba}$ & $\mathrm{Mn}, \mathrm{Cu}, \mathrm{Sb}{ }^{*}$ \\
\hline Smoothed & $\mathrm{Ba}, \mathrm{Cr}, \mathrm{Sb}$ & $\mathrm{Ba}, \mathrm{Cr}, \mathrm{Mn}$ & $\mathrm{Ba}$ & $\mathrm{Ba}, \mathrm{Cu}, \mathrm{Sb}, \mathrm{Zn}$ \\
\hline${ }^{*} \mathrm{p}<0.06$ & & &
\end{tabular}

